\title{
The Quality of Transparent Soap with Addition of Moringa Leaf Extract
}

\author{
Windi Eka Syah Putri \\ Technology and Vocational Education \\ Universitas Negeri Surabaya \\ Surabaya, Indonesia \\ windiputri16070895021@mhs.unesa.ac.id
}

\begin{abstract}
This study was designed to know the effect of moringa leaf extract addition toward transparent soap quality. The quality are foam ability, $\mathrm{pH}$ and microbial contamination, as well as to determine the best concentration of the addition of moringa leaf extract.Type of this study is true experimental design. Data were analyzed statistically using single ANOVA,and followed by Duncan test if has a significant effect $(>5 \%)$. The control group is transparent soap and the experimental group is transparent soap with addition of $0.1 \% ; 0.15 \%$ and $0.2 \%$ moringa leaf extract.The results showed that there was significant effect of moringa leaf extract addition toward on foam ability and $\mathrm{pH}(>5 \%)$. But there was not significant effect on microbial contamination $(<5 \%)$. The less addition of Moringa leaf extract to transparent soap more easily foaming. The more addition of Moringa leaf extract to transparent soap getting lower pH and less microbial contamination. transparent soap with the addition of Moringa leaf extract is feasible to be developed and should be tested antioxidants to know the content on transparent soap.
\end{abstract}

Keywords - transparent soap; moringa leaf extract; transparent soap quality

\section{INTRODUCTION}

Solid soap consists of opaque, translucent and transparent soap. Based on a survey in beauty salons and shops, the soaps that much in demand is transparent solid soap, because it has an attractive appearance, more efficient and have benefits that are not different with liquid soap [7]. Glycerin content in transparent soap serves as a moisturizer on the skin so it is suitable for use as a beauty soap. A good soap can not only cleanse the skin from dirt but also can remove free radicals attached. The effects of free radicals on the skin that are premature aging, characterized by rapid skin wrinkles and dark spots. One way to counteract free radicals in the skin is to use antioxidants. Antioxidants are useful for treating beauty and improve skin protection [1]. Antioxidants not only have functions when the product is applied, but also serves as protection (preservation). The common antioxidant used in soap products is Butyl Hydroxy Toluene (BHT) which is a synthetic antioxidant and is considered less safe for excessive skin use.

Currently beauty products with natural ingredients extract are very popular because it is considered safer for the skin. The addition of natural ingredients extract with antioxidant content on transparent soap is blueberry, blackberry, basil and green tea extract. Transparent antioxidant soap used in this study is a natural antioxidant that is moringa leaf extract. Moringa is known as a magical plant or 'tree of life' and moringa is considered a nutritious plant [6]. In Indonesia, moringa is a plant that is easy to find and the price is very cheap. Moringa content of the most prominent are antioxidants, especially leaves that contain high antioxidants. In addition to antioxidants, it also functions as an antifungal and antibacterial [8-9].Moringa has been developed to be an additive for health and beauty. The addition of Moringa leaf extract ranging from concentration of $0.1 \%$ to $0.15 \%$, because it will interfere with soap transparency if more than that. [5][12].

Based on the description, the purpose of this research is to know the effect of addition of leaf extract of kelor to transparent soap quality that is foam ability, $\mathrm{pH}$ and microbial contamination.

\section{MATERIALS AND METHODS}

This type of research is True Experimental Design. The control group of this study was transparent soap without the addition of Moringa leaf extract, and the experimental group was the addition of $0.1 \%$ maize leaf extract; $0.15 \% ; 0.2 \%$ in transparent soap. This research was conducted at Sciences Laboratory, PKK Department, Faculty of Engineering, State University of Surabaya. Microbiological tests conducted at the Biology Laboratory of Mathematics and Natural Sciences Faculty, Universitas Negeri Surabaya.

\section{A. Variables and Definitions Operational Variables}

Independent variables in this study were addition of Moringa leaf extract that is $0.1 \% ; 0.15 \% ; 0.2 \%$ on transparent soap. Dependent variable in this research is transparent soap quality that is foam ability, $\mathrm{pH}$ and microbial contamination.

Transparent soap organoleptic test is the transparent soap foam ability is very easy to foam.pH test using $\mathrm{pH}$ meter and maximum $\mathrm{pH}$ expected is 11 , microbiological test is done by total plate number method (ALT) with maximum microbial contamination that is 100000 colonies.

The control variable of this research is the extracted Moringa leaves that is in the form of powder of Kolorina premium kelor leaf derived from $100 \%$ moringa leaves without stalk processed by Moringa Indonesia typical method [10] . Tools used, as shown in table I 
TABLE I. TOOLS OF TRANSPARENT SOAP MAKING

\begin{tabular}{|c|l|c|}
\hline No & \multicolumn{1}{|c|}{ Tools } & Total \\
\hline 1 & Plastic Cup & Sufficiently \\
\hline 2 & Measuring cup 500ml & 1 \\
\hline 3 & Electric stove & 1 \\
\hline 4 & Metal Analitical Scales & 1 \\
\hline 5 & Glass Spatula & 2 \\
\hline 6 & Plastic Filter & 1 \\
\hline 7 & Plastic Mold & 3 \\
\hline
\end{tabular}

Materials used, as shown in table II.

TABLE II. MATERIALS OF TRANSPARENT SOAP

\begin{tabular}{|c|l|c|}
\hline No & \multicolumn{1}{|c|}{ Tools } & Total $(\mathrm{g})$ \\
\hline 1 & Stearic acid & 7 \\
\hline 2 & Castor oil & 10 \\
\hline 3 & Coconut Oil & 10 \\
\hline 4 & $30 \% \mathrm{NaOH}$ & 18 \\
\hline 5 & Ethanol & 15 \\
\hline 6 & Glycerin & 13 \\
\hline 7 & Sugar & 7.5 \\
\hline 8 & Citric Acid & 3 \\
\hline 9 & Betain & 5 \\
\hline 10 & Water & 4.5 \\
\hline
\end{tabular}

- $\quad$ The soap making process [3-4]

\section{B. Research Procedure}

\section{- Preparation}

Materials and Tools preparation, equipment used in a clean and terilization tool used $70 \%$ alcohol.Moringa leaf extraction, moringa leaf powder extracted with $96 \%$ ethanol solvent with 1: 9 ratio for 72 hours, then filtered thrice using filter paper. The filtration results are reprocessed by evaporation and produce a viscous extract.

\section{- Implementation}

Performed pre experiment 6 times starting from the test of transparent soap formula and the addition of extracts starting from $0.1 \%$ to $0.3 \%$. Soap formula test was performed to determine soap results without using Moringa leaf extract. The formula test was performed in accordance with the formula by Hambali (2005)[3]. The test results of transparent soap formula are shown in Table III.

TABLE III. TRIAL RESULTS OF TRANSPARENT SOAP FORMULA

\begin{tabular}{|c|l|l|}
\hline No. & \multicolumn{1}{|c|}{ Spesification } & \multicolumn{1}{c|}{ Result } \\
\hline 1. & Color & White (Not Transparent) \\
\hline 2. & Aroma & Stinging oil \\
\hline 3. & Texture & Not Solid \\
\hline
\end{tabular}

Based on formula results test, it can not be called a transparent solid soap. So researcher do modification of transparent soap formula with reduction of citric acid to $1 \mathrm{gr}$ and addition of $1 \mathrm{~g}$ perfume

Stearic acid is melted at $60^{\circ}-70^{\circ} \mathrm{C}$ with the aid of a spatula.Oil mixed on stearic acid with consistent homogeneous temperature. $30 \% \mathrm{NaOH}$ is poured onto a mixture of stearic acid and castor oil at a temperature of $70^{\circ}$ $80^{\circ}$ C. (Sowing Process), stirred continuously until homogeneous.Temperatures raised to $70^{\circ}-80^{\circ} \mathrm{C}$ are mixed with ethanol, glycerin, sugar solution (sugar and water), betaine, citric acid stirred to homogeneous.Temperature is lowered to $40^{\circ}$, and added deodorizer and Moringa leaf extract, this liquid mass of soap is a ready-to-print. Soap printing.At $30^{\circ}$ the soap can harden all night or at lower room temperatures, soap hardening may take several days. Before use, soap should be stored for 2-3 weeks, because in that time soap is still reacting and this process is called aging period.

\section{Data Collection Techniques}

Organoleptic test performed is the acceptance test which includes the favorite test/hedonic Organoleptic test using observation method. Observation was done to get quantitative data that is knowing the effect of addition of Moringa leaf extract $(0.1 \%, 0.15 \%, 0.2 \%)$ to quality (foam ability) of transparent soap. The assessment scale used is 1-4 with the number of panelists 30 people. Panelists which consists of 27 panelists are students of S1 Pendidikan Tata Rias, Universitas Negeri Surabaya (force 2011-2014) and with randomly selected students (26 female and 1 male). Then 3 lecturers of tata boga, tata busana and tata rias, Universitas Negeri Surabaya (all female).

$\mathrm{pH}$ test using $\mathrm{pH}$ meter. The $\mathrm{pH}$ test was performed at the Physical Chemistry Laboratory of Mathematics and Sciences Faculty, Universitas Negeri Surabaya. And microbiological test was conducted at Biology Laboratory of Mathematics and Sciences Faculty, Universiasy Negeri Surabaya by using Total Plate Count Method (ALT).

\section{Data Analysis Technique}

Data analysis used descriptive analysis technique to know the following things are addition of $[0.1 \% ; 0.15 \%$; $0.2 \%$ ] kelor leaf extract to foam ability, $\mathrm{pH}$ and microbial contamination of transparent soap. Data analysis technique used Single ANOVA. If the results indicate any real effect $(\geq 0.05 \%)$ continued with the Duncan test. This study was analyzed with SPSS program version 16.

\section{RESULTS AND DISSCUSSION}

\section{A. Result}

Statistical analysis using single anova (one way anova). The mean results of Moringa leaf extract addition X1 $(0.1 \%)$, $\mathrm{X} 2(0.15 \%), \mathrm{X} 3(0.2 \%)$ to transparent soap quality are foam ability, $\mathrm{pH}$ and microbial contamination. The mean results are presented in Table IV.

The result of single anova analysis obtained $\mathrm{F}$ hitung equal to 37.589 with significant value $0.000(\mathrm{sig}=<0.05)$ it can be concluded that there is significant effect of addition of moringa leaf extract to transparent soap foam ability.

TABLE IV. MEAN RESULT OF TRANSPARENT SOAP

\begin{tabular}{|c|c|c|c|}
\hline Soap & $\begin{array}{c}\text { Foam } \\
\text { Ability }\end{array}$ & pH & $\begin{array}{c}\text { Microbial } \\
\text { Contamination }\end{array}$ \\
\hline $\mathrm{S}_{0.1}$ & 3.60 & 10.3 & 172 \\
\hline $\mathrm{S}_{0.15}$ & 2.90 & 9.8 & 102 \\
\hline $\mathrm{S}_{0.2}$ & 2.13 & 9.2 & 84 \\
\hline
\end{tabular}

Based on the Duncan test results it can be seen that the transparent soap foam ability has a significant difference, it is 
evident that the three Duncan test results occupy different columns. The less of Moringa leaf extract addition to transparent soap, so it very easy to foaming. Moringa leaf extraction using ethanol solvent and has a very slick extract results. The more extracts of Moringa leaves are added, the impression will diminish and affect the resulting foam. The content of ethanol in kelor leaf extract affects the resulting foam. The content of methanol and ethanol which are fatty acid esters as volatile compounds and these compounds can give anti foam effect on soap [11]. While the soap making material that has an important effect on soap scum is Betain. Betain is a surfactant with foaming, wetting, and emulsifying properties [2].

The $\mathrm{pH}$ value (acidity degree) of transparent soap is shown in table $\mathrm{V}$.

TABLE V. pH VALUE OF TRANSPARENT SOAP

\begin{tabular}{|c|c|c|c|c|}
\hline \multirow{2}{*}{ No } & \multicolumn{4}{|c|}{ Test } \\
\cline { 2 - 5 } & $\mathbf{1}$ & $\mathbf{2}$ & $\mathbf{3}$ & Average \\
\hline $\mathrm{S}_{0.1}$ & 10.54 & 10.51 & 10.51 & 10.52 \\
\hline $\mathrm{S}_{0.15}$ & 10.16 & 10.17 & 10.16 & 10.16 \\
\hline $\mathrm{S}_{0.2}$ & 9.62 & 9.60 & 9.59 & 9.6 \\
\hline
\end{tabular}

The results of a single anova analysis $\mathrm{pH}$ obtained F_hitung amounted to 3.391 with a significant value of 0.000 $(\overline{s i g}=<0.05)$ it can be concluded that there is a significant effect of moringa leaf extract addition to transparent soap $\mathrm{pH}$. And based on Duncan test results it can be seen that transparent soap $\mathrm{pH}$ has significant differences, it is evident that the three Duncan test results occupy different columns. The more addition of Moringa leaf extract to transparent soap, so $\mathrm{pH}$ is getting lower.

This is because Moringa leaf extract contains vitamin $\mathrm{C}$, where vitamin $\mathrm{C}$ is acidic so as to decrease the $\mathrm{pH}$ value of the product [5]. $\mathrm{pH}$ instability can be caused by the heating factor, due to the hydrolysis of active ingredients of sodium ester with fatty acid so that there is free alkali which can increase the $\mathrm{pH}$. This $\mathrm{PH}$ is in accordance with SNI 06-3532-1994 which is still within the range of $8-11$, because if it is too high and low it will irritate the skin [12] and this soap can be used for the body and not for the face.

Based on the microbiological test results of transparent soap contain microbial contamination, but still below the maximum limit of microbial contamination $\left(10^{5}\right)$ on soap. Microbiological test results are shown in Table VI.

TABLE VI. MICROBIOLOGICAL TEST RESULT OFTRANSPARENT SOAP

\begin{tabular}{|c|c|c|c|c|}
\hline \multirow{2}{*}{ Soap } & \multicolumn{3}{|c|}{ The number of microbes in the } & \multirow{2}{*}{ Average } \\
& \multicolumn{3}{|c|}{ dilution to- } & \\
\cline { 2 - 4 } & $\mathbf{2}$ & $\mathbf{3}$ & $\mathbf{4}$ & \\
\hline $\mathrm{S}_{0.1}$ & 290 & 157 & 69 & 172 \\
\hline $\mathrm{S}_{0.15}$ & 143 & 109 & 54 & 102 \\
\hline $\mathrm{S}_{0.2}$ & 138 & 84 & 31 & 84 \\
\hline
\end{tabular}

Based on table 9, that the result of single anova analysis obtained F_hitung equal to 1,140 with significant value 0.380 $(\operatorname{sig} \geq 0.05)$ it can be concluded that there is no effect of moringa leaf extract addition to transparent soap microbial contaminatio. Therefore it is not followed by Duncan test.

This is because Moringa leaf extract contains antioxidants. In soap, antioxidants are additives that have the function of reducing rancid odor because it can inhibit or prevent oxidation process. Microbial contamination on transparent soap with Moringa leaf extract is still below the maximum limit set by SNI $\left(10^{5}\right.$ colonies $)$. Hal ini sesuai dengan beberapa hasil penelitian yang mengungkapkan bahwa, moringa leaf extract mampu mengurangi cemaran mrikroba seperti E.Coli, Salmonella, S. aureus dan P. aeruginosa [9].

\section{CONCLUSION}

There are significant effect of addition of Moringa leaf extract to transparent soap foam ability and $\mathrm{pH}$, but no significant effect on microbial contamination. The less addition of Moringa leaf extract to transparent soap more easily foaming. The more addition of Moringa leaf extract to transparent soap gettinglower $\mathrm{pH}$ and less microbial contamination.

\section{REFERENCES}

[1] A.M. Juncan, Analysisi of some antioxidants used in cosmetics by chromatographic methodes, Romania: Babe Ş- Bolyai of University, 2011.

[2] A.O. Barel, M. Paye and H.I. Maibach, Handbook of cosmetic science and technology, $3^{\text {rd }}$ ed , NewYork: Informa Healthcare, 2009, pp. 771777.

[3] E. Hambali, A. Suryani, and M. Rifai, Membuat sabun tranparan untuk gift dan kecantikan, Jakarta: Penebar Swadaya, 2005.

[4] E. Hambali, Jarak pagar tanaman penghasil biodesel”, Jarakrta: Penebar Swadaya, 2007.

[5] F. Hardiyanthi, Pemanfaatan aktivitas antioksidan ekstrak daun kelo (Moringa Oleifera) dalam sediaan hand and body cream, Jakarta: FST UIN Syari Hidayatullah, 2015.

[6] H. Bourekoua, "Evaluation of Physical; sensorial; and antioxidan properties of gluten-free bread enriched with moringa oleifera leaf powder", 2017.

[7] I.A.R. Putri, Pengaruh penambahan sari aloevera terhadap sifat fisik dan masa simpan sediaan sabun transparan untuk wajah, Surabaya: Universitas Negeri Surabaya, 2014

[8] J. A. Parrotta, Moringa oliefera, U.S: United States Department of Agriculture, 2015.

[9] J.R.O. Peixoto, In vitro antibacterial effect of aqueous and ethanolic moringa leaf extract, Brazil, 2011, pp 201-204.

[10] Krisnadi, A. Dudi. Kelor super nutrisi. Blora: Pusat Informasi dan Pengembangan Tanaman Kelor Indonesia. 2015.

[11] S. Hasibuan, Sahirman, and A. Ma'ruf, The quality of transparent soap from farmer's crude calophyllum seed oil, Indonesia, 2014.

[12] T. Anggraini, S. D. Ismanto and Dahlia, The making of transparent soap from green tea extract, Indonesia, 2015. 